\title{
Pengaruh Takaran Pupuk Kandang Sapi dan Jarak Tanam Terhadap Pembentukan Umbi Siung Tunggal Bawang Putih Lokal (Allium sativum, L)
}

\author{
Angelius Fallo ${ }^{a}$ dan Maria Afnita Lelang ${ }^{b}$ \\ ${ }^{a}$ Fakultas Pertanian, Universitas Timor, Kefamenanu, TTU - NTT, Indonesia. \\ ${ }^{b}$ Fakultas Pertanian, Universitas Timor, Kefamenanu, TTU - NTT, Indonesia.
}

\section{Article Info}

\section{Article history:}

Received 22 Maret 2016

Received in revised form 28 Maret 2016

Accepted 20 April 2016

\section{Keywords:}

Pupuk Kandang Sap

Jarak Tanam

Siung Tunggal

Allium sativum, $L$

\begin{abstract}
Abstrak
Meningkatkan pemupukan dapat meningkatan pertumbuhan dan hasil tanaman, dan kerenanya perlu jarak tanam yang sesuai. Mengurangi jarak tanam pada bawang putih meningkatkan kompetisi antar tanaman dan diduga memacu peningkatan terbentuknya umbi suing tunggal yang memiliki nilai ekonomis lebih tinggi. Penelitian ini bertujuan untuk mengetahui pengaruh jarak tanam dan takaran pupuk kandang sapi terhadap pembentukan umbi siung tunggal bawang putih lokal menggunakan Rancangan Acak Kelompok (RAK) faktorial diulang tiga kali. Faktor pertama adalah takaran pupuk kandang sapi yang terdiri dari 3 aras yaitu $10 \mathrm{t} / \mathrm{ha}, 15 \mathrm{t} / \mathrm{ha}$ dan $20 \mathrm{t} / \mathrm{ha}$. Faktor kedua adalah jarak tanam yang terdiri dari 3 aras yaitu $5 \mathrm{~cm}$ x $5 \mathrm{~cm}, 5 \mathrm{~cm}$ x $10 \mathrm{~cm}$ dan $10 \mathrm{~cm}$ x $10 \mathrm{~cm}$. Hasil penelitian menunjukkan bahwa interaksi antara takaran pupuk kandang sapi dan jarak tanam terjadi terhadap pengamatan hasil; jumlah umbi siung tunggal perpetak, berat kering umbi majemuk perpetak, berat kering siung tunggal per petak, persentase siung tunggal per petak dan indeks panen. Pemberian takaran pupuk kandang sapi $15 \mathrm{t} / \mathrm{ha}$ dengan jarak tanam $5 \mathrm{~cm}$ x $5 \mathrm{~cm}$ memberikan hasil berat kering umbi bawang putih siung tunggal 2,28 t/ha dengan persentase jumlah umbi siung tunggal per petak 86,42\%. (92016 dipublikasikan oleh Savana Cendana.
\end{abstract}

\section{Pendahuluan}

Bawang putih (Allium sativum, L.) siung tunggal dari jenis lokal merupakan komoditas pertanian yang banyak mendatangkan keuntungan karena mempunyai nilai ekonomis yang tinggi dibandingkan dengan bawang putih lokal biasa. Bawang putih lokal adalah tanaman asli sub tropika yang dikembangkan di daerah dataran tinggi. Umbi bawang putih banyak digunakan sebagai bumbu masak. Selain itu, bawang putihdiyakini oleh masyarakat dapat digunakan sebagai bahan obat, antara lain untuk pengobatan penyakit jantung, darah tinggi, kelebihan kolestrol, trombosit rendah dan diabetes. Pemanfaatan bawang putih untuk pengobatan alternatif dan untuk peningkatan daya tahan tubuh., umumnya dilakukan dengan mengkonsumsinya dalam bentuk segar, kapsul atau cairan yang belum dimasak. Sebab perebusan atau pemasakan bawang putih bisa berakibat hilangnya zat allicin yang dipercaya berkhasiat sebagi bahan obat (Fauziah dan Hening, 2000). Umbi bawang putih terdiri dari zat organis yaitu: protein $(4,50 \mathrm{~g})$, lemak $(0,20 \mathrm{~g})$ dan hidrat arang $(23,10 \mathrm{~g})$. Selain itu terdapat kalsium (42 mg), fosfor (134 mg), besi (1 mg), vitamin C (15 mg), vitamin B1 (0,22 mg), air (71 g) dan kalori (95 kal). (Direktorat Gizi Departemen Kesehatan RI, 1997).

Kebutuhan (konsumsi) bawang putih dari tahun ke tahun terus meningkat sejalan dengan meningkatnya jumlah penduduk, semakin membaiknya perekonomian nasional dan semakin meningkatnya pengetahuan masyarakat akan pentingnya gizi komoditas tersebut. Selain itu permintaan bawang putih siung tunggal (bawang lanang) jenis lokal yang semakin diminati konsumsinya oleh masyarakat karena mempunyai nilai ekonomi tinggi. Namun, meningkatnya permintaan tersebut belum mampu diimbangi dengan peningkatan produksi. Hal ini disebabkan oleh luas tanam dan produktivitas hasil yang rendah (Rismunandar, 2003).

Tabel 1. Data Produksi Bawang Putih di Indonesia 5 tahun terakhir

\begin{tabular}{cc}
\hline Tahun & Produksi/Ton \\
\hline 2009 & 15419 \\
2010 & 12295 \\
2011 & 14749 \\
2012 & 17638 \\
2013 & 75867 \\
\hline
\end{tabular}

Badan Pusat Statistik Republik Indonesia Jakarta Pusat, 2013

Berdasarkan hasil wawancara dengan beberapa petani di Desa Fatuneno, bahwa produksi bawang putih di TTU khususnya bawang putih siung tunggal sangatlah terbatas, sementara permintaan akan bawang tersebut semakin hari semakin meningkat. Untuk menjawab permasalahan tersebut maka peneliti ingin melakukan penelitian tentang jarak tanam serta takaran pupuk kandang sapi yang tepat sehingga dapat memperoleh pertumbuhan dan hasil siung tunggal bawang putih lokal yang maksimal.

\section{Metode}

Penelitian dilaksanakan bulan Juni-September 2015 di kebun petani Desa Taekas, Kecamatan Miomaffo Timur, Kabupaten Timor Tengah Utara, Propinsi Nusa Tenggara Timur. Percobaan lapangan menggunakan Rancangan Acak Kelompok (RAK) faktorial $3 \times 3$ dengan 3 ulangan sebagai berikut : faktor pertama adalah pengaruh takaran pupuk kandang sapi $(\mathrm{P})$ terdiri dari 3 aras yaitu $\mathrm{P}_{1}(10 \mathrm{t} / \mathrm{ha}$ setara dengan $1 \mathrm{~kg} /$ petak $), \mathrm{P}_{2}(15 \mathrm{t} /$ ha setara dengan $1,5 \mathrm{~kg} /$ petak $), \mathrm{P}_{3}$ (20 t/ha setara dengan $2 \mathrm{~kg} /$ petak). Faktor kedua adalah pengaruh jarak tanam $(\mathrm{J})$ terdiri dari 3 aras yaitu $J_{1}(5 \mathrm{~cm} \mathrm{x} 5 \mathrm{~cm}), J_{2}(5 \mathrm{~cm} \mathrm{x} 10 \mathrm{~cm}), J_{3}(10 \mathrm{~cm} \mathrm{x} 10 \mathrm{~cm})$. Data hasil pengamatan kemudian dianalisis dengan menggunakan sidik ragam (Anova) Rancangan Acak Kelompok Lengkap (RAK). Rata-rata perlakuan selanjutnya diuji lanjut dengan menggunakan Duncan Multiple Range Test (DMRT) dengan tingkat signifikasi 5\% sesuai petunjuk Gomez dan Gomez, (1995). Analisis data menggunakan program SAS 9.1.

\section{Hasil dan Pembahasan}

3.1 Hasil

Interaksi antar perlakuan jarak tanam dengan takaran pupuk kandang sapi tidak terjadi terhadap suhu tanah pada setiap waktu pengamatan 25, 50 dan 75 HST. Pengaruh utama perlakuan takaran pupuk kandang tidak nyata terhadap suhu tanah pada 25 dan 50 HST. Pada 75 HST suhu tanah tertinggi terjadi pada petak yang diberi perlakuan takaran pupuk 15 t/ha berbeda nyata dibanding suhu tanah terendah pada petak yang diberi perlakuan $10 \mathrm{t} / \mathrm{ha}$. Pengaruh utama perlakuan jarak tanam terjadi pada pengamatan 25 dan 75 HST. Pada pengamatan 25 HST petak dengan jarak tanam $10 \mathrm{~cm} \times 10 \mathrm{~cm}$ terdapat suhu tanah tertinggi, sedangkan pada pengamatan 75 HST suhu tanah tertinggi terdapat pada petak dengan jarak tanam $10 \mathrm{~cm}$ x $10 \mathrm{~cm}$ (Tabel 2.).

Tabel. 2 Suhu Tanah $\left({ }^{\circ} \mathrm{C}\right)$

\begin{tabular}{cccccc}
\hline Waktu & Takaran & \multicolumn{3}{c}{ Jarak Tanam $(\mathrm{cm} \mathrm{x} \mathrm{cm})$} & \multirow{2}{*}{ Rerata } \\
\cline { 2 - 5 } Pengamatan & Pupuk (t/ha) & $5 \times 5$ & $5 \times 10$ & $10 \times 10$ & \\
\hline \multirow{3}{*}{25 HST } & 10 & 29.39 & 28.60 & 29.73 & $29.24 \mathrm{a}$ \\
& 15 & 28.63 & 27.90 & 31.17 & $29.23 \mathrm{a}$ \\
& 20 & 27.94 & 30.84 & 31.10 & $29.96 \mathrm{a}$ \\
\cline { 2 - 5 } & Rerata & $28.66 \mathrm{~b}$ & $29.11 \mathrm{ab}$ & $30.67 \mathrm{a}$ & $(-)$ \\
\hline \multirow{3}{*}{$50 \mathrm{HST}$} & 10 & 29.74 & 29.46 & 28.16 & $29.12 \mathrm{a}$ \\
& 15 & 29.07 & 27.19 & 31.19 & $29.15 \mathrm{a}$ \\
& 20 & 26.63 & 31.50 & 30.76 & $29.63 \mathrm{a}$ \\
\hline \multirow{3}{*}{75 HST } & Rerata & $28.48 \mathrm{a}$ & $29.38 \mathrm{a}$ & $30.03 \mathrm{a}$ & $(-)$ \\
& 10 & 28.68 & 28.36 & 29.64 & $28.44 \mathrm{~b}$ \\
& 15 & 30.91 & 29.24 & 30.11 & $29.78 \mathrm{a}$ \\
& 20 & 30.16 & 28.58 & 30.52 & $29.39 \mathrm{a}$ \\
\hline & Rerata & $29.91 \mathrm{a}$ & $28.73 \mathrm{~b}$ & $30.9 \mathrm{a}$ & $(-)$
\end{tabular}

Keterangan : Angka pada baris dan kolom diikuti huruf sama menunjukkan tidak berbeda pada taraf nyata $(\alpha) 5 \%$ menurut uji DMRT. $(-)=$ Tidak terjadi interaksi antar faktor.

Tabel 3. Kadar Lengas Tanah (\%)

\begin{tabular}{cccccc}
\hline Waktu & Takaran & \multicolumn{3}{c}{ Jarak Tanam $(\mathrm{cm} \mathrm{x} \mathrm{cm})$} & \multirow{2}{*}{ Rerata } \\
\cline { 2 - 5 } Pengamatan & Pupuk (t/ha) & $5 \times 5$ & $5 \times 10$ & $10 \times 10$ & \\
\hline \multirow{3}{*}{25 HST } & 10 & 13.42 & 15.66 & 12.88 & $13.99 \mathrm{ab}$ \\
& 15 & 11.21 & 12.66 & 10.35 & $11.41 \mathrm{~b}$ \\
& 20 & 15.23 & 15.04 & 14.11 & $14.79 \mathrm{a}$ \\
\cline { 2 - 5 } & Rerata & $13.29 \mathrm{a}$ & $14.45 \mathrm{a}$ & $12.45 \mathrm{a}$ & $(-)$ \\
\hline \multirow{3}{*}{$50 \mathrm{HST}$} & 10 & 18.68 & 19.11 & 14.24 & $17.34 \mathrm{a}$ \\
& 15 & 12.94 & 19.12 & 19.43 & $17.16 \mathrm{a}$ \\
& 20 & 16.62 & 15.35 & 14.59 & $15.52 \mathrm{a}$ \\
\hline \multirow{3}{*}{75 HST } & Rerata & $16.08 \mathrm{a}$ & $17.86 \mathrm{a}$ & $16.09 \mathrm{a}$ & $(-)$ \\
& 10 & 12.83 & 14.56 & 14.24 & $13.88 \mathrm{a}$ \\
& 15 & 11.98 & 18.04 & 19.43 & $16.49 \mathrm{a}$ \\
& 20 & 13.34 & 15.72 & 13.72 & $14.26 \mathrm{a}$ \\
\hline & Rerata & $12.72 \mathrm{a}$ & $16.11 \mathrm{a}$ & $15.80 \mathrm{a}$ & $(-)$ \\
\hline
\end{tabular}

Keterangan : Angka pada baris dan kolom diikuti huruf sama menunjukkan tidak berbeda pada taraf nyata $(\alpha) 5 \%$ menurut uji DMRT. $(-)=$ Tidak terjadi interaksi antar faktor.

Interaksi antar perlakuan tidak terjadi, demikian pula pengaruh utama perlakuan jarak tanam tidak nyata terhadap kadar lengas tanah setiap waktu pengamatan 25, 50 dan 75 HST. Pengaruh utama perlakuan takaran pupuk kandang sapi terjadi pada petak yang diberi 20 t/ha, terdapat kadar lengas tanah tertinggi pada pengamatan 25 HST (Tabel 3.).

Interaksi antar perlakuan dan pengaruh utama masing-masing perlakuan tidak terjadi terhadap berat volume tanah setiap waktu pengamatan (Tabel 4). 
Tabel 4. Berat Volume Tanah $\left(\mathrm{g} / \mathrm{cm}^{3}\right)$

\begin{tabular}{cccccc}
\hline Waktu & Takaran & \multicolumn{3}{c}{ Jarak Tanam $(\mathrm{cm} \mathrm{x} \mathrm{cm})$} & \multirow{2}{*}{ Rerata } \\
\cline { 2 - 5 } & Pupuk (t/ha) & $5 \times 5$ & $5 \times 10$ & $10 \times 10$ & \\
\hline \multirow{3}{*}{$25 \mathrm{HST}$} & 10 & 1.98 & 1.69 & 1.69 & $1.79 \mathrm{a}$ \\
& 15 & 2.03 & 1.94 & 1.85 & $1.94 \mathrm{a}$ \\
& 20 & 1.90 & 1.85 & 1.68 & $1.81 \mathrm{a}$ \\
\cline { 2 - 5 } $50 \mathrm{HST}$ & Rerata & $1.97 \mathrm{a}$ & $1.83 \mathrm{a}$ & $1.74 \mathrm{a}$ & $(-)$ \\
\hline & 10 & 1.71 & 1.84 & 2.04 & $1.86 \mathrm{a}$ \\
& 15 & 1.90 & 1.78 & 1.92 & $1.87 \mathrm{a}$ \\
& 20 & 1.90 & 1.84 & 1.88 & $1.87 \mathrm{a}$ \\
\hline \multirow{3}{*}{$75 \mathrm{HST}$} & Rerata & $1.84 \mathrm{a}$ & $1.82 \mathrm{a}$ & $1.95 \mathrm{a}$ & $(-)$ \\
& 10 & 1.82 & 1.97 & 2.04 & $1.95 \mathrm{a}$ \\
& 15 & 1.90 & 1.89 & 1.92 & $1.90 \mathrm{a}$ \\
& 20 & 2.06 & 1.83 & 1.94 & $1.94 \mathrm{a}$ \\
\hline
\end{tabular}

Keterangan : Angka pada baris dan kolom diikuti huruf sama menunjukkan tidak berbeda pada taraf nyata $(\alpha) 5 \%$ menurut uji DMRT. $(-)=$ Tidak terjadi interaksi antar faktor.

Tabel 5. Jumlah Daun (Helai)

\begin{tabular}{cccccc}
\hline \multirow{2}{*}{$\begin{array}{c}\text { Waktu } \\
\text { Pengamatan }\end{array}$} & Takaran & \multicolumn{3}{c}{ Jarak Tanam $(\mathrm{cm} \times \mathrm{cm})$} & \multirow{2}{*}{ Rerata } \\
\cline { 2 - 5 } $25 \mathrm{HST}$ & 10 & 4.37 & 4.33 & 4.33 & $4.34 \mathrm{a}$ \\
& 15 & 4.47 & 4.30 & 4.27 & $4.34 \mathrm{a}$ \\
& 20 & 4.40 & 4.40 & 4.17 & $4.32 \mathrm{a}$ \\
\cline { 2 - 5 } & Rerata & $4.41 \mathrm{a}$ & $4.34 \mathrm{a}$ & $4.26 \mathrm{a}$ & $(-)$ \\
\hline \multirow{5}{*}{$50 \mathrm{HST}$} & 10 & 5.97 & 6.00 & 6.23 & $6.07 \mathrm{a}$ \\
& 15 & 5.63 & 5.83 & 5.83 & $5.77 \mathrm{a}$ \\
& 20 & 5.93 & 6.10 & 5.73 & $5.92 \mathrm{a}$ \\
\hline \multirow{5}{*}{$75 \mathrm{HST}$} & Rerata & $5.84 \mathrm{a}$ & $5.98 \mathrm{a}$ & $5.93 \mathrm{a}$ & $(-)$ \\
& 10 & 5.23 & 5.17 & 5.33 & $5.24 \mathrm{a}$ \\
& 15 & 5.03 & 5.20 & 5.20 & $5.14 \mathrm{a}$ \\
& 20 & 4.83 & 5.10 & 5.40 & $5.11 \mathrm{a}$ \\
\hline & Rerata & $5.03 \mathrm{a}$ & $5.16 \mathrm{a}$ & $5.31 \mathrm{a}$ & $(-)$ \\
\hline
\end{tabular}

Keterangan : Angka pada baris dan kolom diikuti huruf sama menunjukkan tidak berbed pada taraf nyata $(\alpha) 5 \%$ menurut uji DMRT. $(-)=$ Tidak terjadi interaksi antar faktor.

Interaksi antar perlakuan tidak terjadi pada pengamatan 25, 50 dan 75 HST terhadap tinggi tanaman (Tabel 5.), dan jumlah daun (Tabel 6.). Demikian pula untuk pengaruh utama masing-masing perlakuan.

\begin{tabular}{|c|c|c|c|c|c|}
\hline \multirow{2}{*}{$\begin{array}{c}\text { Waktu } \\
\text { Pengamatan }\end{array}$} & \multirow{2}{*}{$\begin{array}{c}\text { Takaran } \\
\text { Pupuk (t/ha) }\end{array}$} & \multicolumn{3}{|c|}{ Jarak Tanam $(\mathrm{cm} \mathrm{x} \mathrm{cm)}$} & \multirow{2}{*}{ Rerata } \\
\hline & & $5 \times 5$ & $5 \times 10$ & $10 \times 10$ & \\
\hline \multirow{4}{*}{25 HST } & 10 & 26.41 & 24.50 & 25.73 & $25.55 \mathrm{a}$ \\
\hline & 15 & 24.74 & 26.30 & 25.65 & $25.56 \mathrm{a}$ \\
\hline & 20 & 25.63 & 25.02 & 24.64 & $25.10 \mathrm{a}$ \\
\hline & Rerata & $25.60 \mathrm{a}$ & $25.27 \mathrm{a}$ & $25.34 \mathrm{a}$ & $(-)$ \\
\hline \multirow{4}{*}{$50 \mathrm{HST}$} & 10 & 37.03 & 36.99 & 37.21 & $37.07 \mathrm{a}$ \\
\hline & 15 & 34.05 & 35.03 & 35.84 & $34.97 \mathrm{a}$ \\
\hline & 20 & 38.13 & 37.55 & 35.28 & $36.99 \mathrm{a}$ \\
\hline & Rerata & $36.40 \mathrm{a}$ & $36.52 \mathrm{a}$ & $36.11 \mathrm{a}$ & $(-)$ \\
\hline \multirow{3}{*}{75 HST } & 10 & 27.28 & 26.68 & 27.97 & $27.31 \mathrm{a}$ \\
\hline & 15 & 26.23 & 26.70 & 26.53 & $26.48 \mathrm{a}$ \\
\hline & 20 & 26.55 & 26.37 & 27.42 & $26.78 \mathrm{a}$ \\
\hline
\end{tabular}

Keterangan : Angka pada baris dan kolom diikuti huruf sama menunjukkan tidak berbeda pada taraf nyata $(\alpha) 5 \%$ menurut uji DMRT. $(-)=$ Tidak terjadi interaksi antar faktor.

Interaksi antar perlakuan berpengaruh nyata terhadap berat kering tajuk. Berat kering tajuk semakin menurun dengan meningkatnya jarak tanam. Takaran pupuk kandang sapi $15 \mathrm{t} /$ ha dengan jarak tanam $5 \mathrm{~cm}$ x $5 \mathrm{~cm}$ menghasilkan berat kering tajuk paling berat demikian pula pada jarak tanam $5 \mathrm{~cm}$ x $10 \mathrm{~cm}$. Pada jarak tanam $10 \mathrm{~cm} \times 10 \mathrm{~cm}$, pemberian takaran pupuk kandang sapi $10 \mathrm{t} / \mathrm{ha}$ menghasilkan berat kering tajuk yang lebih tinggi dibanding bila diberi takaran $15 \mathrm{t} /$ ha maupun $20 \mathrm{t} / \mathrm{ha}$ (Tabel 7.).

Tabel 7. Berat Kering Tajuk (t/ha)

\begin{tabular}{cllll}
\hline Takaran & \multicolumn{3}{c}{ Jarak Tanam $(\mathrm{cm} \mathrm{x} \mathrm{cm})$} & \multirow{2}{*}{ Rerata } \\
\cline { 2 - 4 } Pupuk (t/ha) & $5 \times 5$ & $5 \times 10$ & $10 \times 10$ & $0.26 \mathrm{~b}$ \\
10 & $0.34 \mathrm{~b}$ & $0.20 \mathrm{f}$ & $0.24 \mathrm{ef}$ & $0.32 \mathrm{a}$ \\
15 & $0.44 \mathrm{a}$ & $0.31 \mathrm{c}$ & $0.22 \mathrm{ef}$ & $0.26 \mathrm{~b}$ \\
\hline 20 & $0.30 \mathrm{~cd}$ & $0.25 \mathrm{~d}$ & $0.23 \mathrm{~g}$ & $(+)$
\end{tabular}

Keterangan : Angka pada baris dan kolom diikuti huruf sama menunjukkan tidak berbeda pada taraf nyata $(\alpha) 5 \%$ menurut uji DMRT. $(-)=$ Tidak terjadi interaksi antar faktor.

Interaksi antar perlakuan berpengaruh nyata terhadap jumlah umbi siung tunggal per petak. Jumlah tanaman yang menghasilkan siung tunggal menurun dengan meningkatnya jarak tanam. Pemberian takaran pupuk kandang sapi 15 t/ha pada semua taraf perlakuan jarak tanam menghasilkan lebih banyak umbi siung tunggal dibanding pada takaran 20 dan 10 t/ha. Pada Jarak tanam $5 \mathrm{~cm}$ x 5 $\mathrm{cm}$, pemberian pupuk kandang sapi takaran $15 \mathrm{t} /$ ha menghasilkan umbi siung tunggal terbanyak dengan persentase $86.43 \%$, berbeda nyata dibanding pemberian pada takaran 10 dan 20 t/ha. Pada jarak tanam $5 \mathrm{~cm} \mathrm{x} 10 \mathrm{~cm}$, pemberian takaran pupuk kandang 15 t/ha menghasilkan jumlah umbi siung tunggal lebih banyak dengan persentase $54.21 \%$ dibanding pada takaran 20 t/ha, dan pada jarak tanam 10 x 10 hasilnya tidak berbeda nyata (Tabel 8).

Tabel 8. Persentase Jumlah Siung Tunggal perPetak (\%)

\begin{tabular}{ccccc}
\hline Takaran & \multicolumn{3}{c}{ Jarak Tanam $(\mathrm{cm} \mathrm{x} \mathrm{cm)}$} & \multirow{2}{*}{ Rerata } \\
\cline { 2 - 4 } Pupuk (t/ha) & $5 \times 5$ & $5 \times 10$ & $10 \times 10$ & \\
\hline 10 & $55.77 \mathrm{c}$ & $45.61 \mathrm{~d}$ & $24.81 \mathrm{f}$ & $42.07 \mathrm{~b}$ \\
15 & $86.43 \mathrm{a}$ & $54.21 \mathrm{~d}$ & $35.19 \mathrm{f}$ & $58.61 \mathrm{a}$ \\
20 & $74.98 \mathrm{~b}$ & $32.46 \mathrm{e}$ & $24.81 \mathrm{f}$ & $44.08 \mathrm{~b}$ \\
\hline Rerata & $72.39 \mathrm{a}$ & $44.09 \mathrm{~b}$ & $28.27 \mathrm{c}$ & $(+)$ \\
\hline
\end{tabular}

Keterangan : Angka pada baris dan kolom diikuti huruf sama menunjukkan tidak berbeda pada taraf nyata $(\alpha) 5 \%$ menurut uji DMRT. $(-)=$ Tidak terjadi interaksi antar faktor.

Interaksi antara takaran pupuk dengan jarak tanam tidak terjadi, namun peningkatan jarak tanam menghasilkan berat kering umbi per tanaman sampel yang cenderung meningkat, namun peningkatan takaran pupuk tidak meningkatkan berat kering umbi pertanaman. Kombinasi antara perlakuan jarak tanam $10 \mathrm{~cm}$ x $10 \mathrm{~cm}$ dan takaran pupuk kandang sapi $20 \mathrm{t} / \mathrm{ha}$ menghasilkan berat kering umbi per tanaman paling berat tetapi tidak berbeda nyata terhadap takaran pupuk $15 \mathrm{t} /$ ha dan $10 \mathrm{t} / \mathrm{ha}$ (Tabel 9.)

Tabel 9. Berat Kering Umbi Per Tanaman (g)

\begin{tabular}{cllll}
\hline Takaran & \multicolumn{3}{c}{ Jarak Tanam $(\mathrm{cm} \mathrm{x} \mathrm{cm)}$} & \multirow{2}{*}{ Rerata } \\
\cline { 2 - 4 } Pupuk (t/ha) & $5 \times 5$ & $5 \times 10$ & $10 \times 10$ & \\
\hline 10 & 0.75 & 1.05 & 1.33 & $1.04 \mathrm{a}$ \\
15 & 1.06 & 1.12 & 1.19 & $1.13 \mathrm{a}$ \\
20 & 1.04 & 1.24 & 1.24 & $1.17 \mathrm{a}$ \\
\hline Rerata & $0.95 \mathrm{a}$ & $1.14 \mathrm{a}$ & $1.25 \mathrm{a}$ & $(-)$ \\
\hline
\end{tabular}

Keterangan : Angka pada baris dan kolom diikuti huruf sama menunjukkan tidak berbeda pada taraf nyata $(\alpha) 5 \%$ menurut uji DMRT. $(-)=$ Tidak terjadi interaksi antar faktor.

Interaksi antar perlakuan terjadi terhadap berat kering umbi majemuk per petak. Pemberian takaran pupuk kandang sapi $15 \mathrm{t} / \mathrm{ha}$ dengan jarak tanam $5 \mathrm{~cm}$ x $10 \mathrm{~cm}$ menghasilkan Berat Kering Umbi Majemuk Per Petak terberat berbeda nyata terhadap semua kombinasi perlakuan lainnya (Tabel 10.).

Tabel 10. Berat Kering Umbi Majemuk Per Petak (t/ha)

\begin{tabular}{clccc}
\hline Takaran & \multicolumn{3}{c}{ Jarak Tanam $(\mathrm{cm} \mathrm{x} \mathrm{cm)}$} & \multirow{2}{*}{ Rerata } \\
\cline { 2 - 4 } Pupuk (t/ha) & $5 \times 5$ & $5 \times 10$ & $10 \times 10$ & \\
\hline 10 & $0.90 \mathrm{e}$ & $1.84 \mathrm{~b}$ & $1.22 \mathrm{~d}$ & 1.32 \\
15 & $1.45 \mathrm{c}$ & $2.18 \mathrm{a}$ & $1.72 \mathrm{~b}$ & 1.78 \\
20 & $1.10 \mathrm{~d}$ & $0.92 \mathrm{e}$ & $1.42 \mathrm{c}$ & 1.15 \\
\hline Rerata & 1.15 & 1.65 & 1.45 & $(+)$ \\
\hline
\end{tabular}

Keterangan : Angka pada baris dan kolom diikuti huruf sama menunjukkan tidak berbed pada taraf nyata $(\alpha) 5 \%$ menurut uji DMRT. $(-)$ = Tidak terjadi interaksi antar faktor.

Interaksi antar perlakuan terjadi terhadap berat kering umbi siung tunggal per petak. Pemberian takaran pupuk kandang 15 t/ha menghasilkan berat lebih tinggi pada setiap taraf jarak tanam, dan tanaman yang diberi perlakuan takaran pupuk kandang sapi 15 t/ha dengan jarak tanam $5 \mathrm{~cm}$ x $5 \mathrm{~cm}$ menghasilkan berat kering siung tunggal per petak tertinggi. Pemberian takaran pupuk kandang 10 t/ha dengan jarak tanam $5 \mathrm{~cm} \times 5 \mathrm{~cm}$ dan $10 \mathrm{~cm} \times 10 \mathrm{~cm}$ hasilnya lebih tinggi dibanding pemberian takaran pupuk kandang 20 t/ha dengan jarak tanam yang sama (Tabel 11.)

Pengamatan lebih lanjut pengaruh utama perlakuan jarak tanam menunjukkan bahwa penurunan jarak tanam dari $10 \mathrm{~cm}$ x $10 \mathrm{~cm}$ menjadi $5 \mathrm{~cm} \times$ $10 \mathrm{~cm}$ meningkatkan hasil berat kering umbi siung tunggal dari $0,41 \mathrm{t} / \mathrm{ha}$ menjadi $0,88 \mathrm{t} / \mathrm{ha}$ terdapat selisih sebesar $0,47 \mathrm{t} / \mathrm{ha}$ ini menunjukkan terjadi peningkatan sebesar $115 \%$ sama dengan pencapaian dari penurunan jarak tanam dari $5 \mathrm{~cm} \mathrm{x}$ $10 \mathrm{~cm}$ ke $5 \mathrm{~cm}$ x $5 \mathrm{~cm}$ (Tabel 11.)

Tabel 11. Berat Kering Umbi Siung Tunggal Per Petak (t/ha)

\begin{tabular}{ccccc}
\hline Takaran & \multicolumn{3}{c}{ Jarak Tanam $(\mathrm{cm} \mathrm{x} \mathrm{cm)}$} & \multirow{2}{*}{ Rerata } \\
\cline { 2 - 4 } Pupuk (t/ha) & $5 \times 5$ & $5 \times 10$ & $10 \times 10$ & \\
\hline 10 & $1.82 \mathrm{~b}$ & $0.63 \mathrm{e}$ & $0.42 \mathrm{fg}$ & $0.96 \mathrm{~b}$ \\
15 & $2.28 \mathrm{a}$ & $1.04 \mathrm{~d}$ & $0.51 \mathrm{ef}$ & $1.28 \mathrm{a}$ \\
20 & $1.60 \mathrm{c}$ & $0.98 \mathrm{~d}$ & $0.31 \mathrm{~g}$ & $0.97 \mathrm{~b}$ \\
\hline Rerata & $1.90 \mathrm{a}$ & $0.88 \mathrm{~b}$ & $0.41 \mathrm{c}$ & $(+)$
\end{tabular}

Keterangan : Angka pada baris dan kolom diikuti huruf sama menunjukkan tidak berbeda pada taraf nyata $(\alpha) 5 \%$ menurut uji DMRT. $(+)=$ Tidak terjadi interaksi antar faktor.

Interaksi antar perlakuan terjadi terhadap berat kering umbi total per petak. Berat kering umbi total tanaman semakin menurun dengan meningkatnya jarak tanam. Pemberian takaran pupuk kandang sapi 15 t/ha pada semua taraf perlakuan jarak tanam menghasilkan berat kering umbi total tanaman lebih tinggi 
dibanding pada takaran 10 dan $20 \mathrm{t} / \mathrm{ha}$, dan pada jarak tanam $5 \mathrm{~cm}$ x $10 \mathrm{~cm}$ menghasilkan berat kering umbi total tanaman paling berat dan berbeda nyata dibanding semua kombinasi perlakuan lainnya. Pada jarak tanam $5 \mathrm{~cm} \times 5 \mathrm{~cm}$, pemberian takaran pupuk kandang $10 \mathrm{t} / \mathrm{ha}$ menghasilkan berat kering umbi total yang tidak berbeda nyata dibanding pada takaran 20 t/ha. (Tabel 12.).

Tabel 12. Berat Kering Total Per Petak (t/ha)

\begin{tabular}{ccccc}
\hline Takaran & \multicolumn{3}{c}{ Jarak Tanam $(\mathrm{cm} \mathrm{x} \mathrm{cm)}$} & \multirow{2}{*}{ Rerata } \\
\cline { 2 - 4 } Pupuk (t/ha) & $5 \times 5$ & $5 \times 10$ & $10 \times 10$ & \\
\hline 10 & $3.04 \mathrm{c}$ & $2.46 \mathrm{~d}$ & $1.31 \mathrm{~g}$ & $2.27 \mathrm{~b}$ \\
15 & $3.28 \mathrm{a}$ & $4.00 \mathrm{~b}$ & $1.96 \mathrm{e}$ & $3.08 \mathrm{a}$ \\
20 & $3.02 \mathrm{c}$ & $2.19 \mathrm{e}$ & $1.81 \mathrm{fg}$ & $2.34 \mathrm{~b}$ \\
\hline Rerata & $3.11 \mathrm{a}$ & $2.88 \mathrm{~b}$ & $1.69 \mathrm{c}$ & $(+)$ \\
\hline
\end{tabular}

Keterangan : Angka pada baris dan kolom diikuti huruf sama menunjukkan tidak berbed pada taraf nyata $(\alpha) 5 \%$ menurut uji DMRT. $(+)=$ Tidak terjadi interaksi antar faktor.

Interaksi antar perlakuan terjadi terhadap persentase berat kering siung tunggal, pada setiap pemberian takaran pupuk kandang, nilainya cenderung semakin menurun dengan meningkatnya jarak tanam. Pemberian Takaran pupuk kandang sapi $15 \mathrm{t} /$ ha dengan jarak tanam $5 \mathrm{~cm}$ x $5 \mathrm{~cm}$ menghasilkan persentase berat kering siung tunggal paling tinggi dan berbeda nyata dibanding semua kombinasi perlakuan lainnya. Pada jarak tanam $5 \mathrm{~cm}$ x $10 \mathrm{~cm}$ pemberian takaran pupuk kandang sapi 20 t/ha menghasilkan persentase berat kering siung tunggal lebih tinggi, sedangkan pada jarak tanam $10 \mathrm{~cm} \mathrm{x} 10 \mathrm{~cm}$, pemberian takaran pupuk kandang sapi 10 t/ha menghasilkan persentase berat kering siung tunggal lebih tinggi (Tabel 13.).

Tabel 13. Persentase Berat Siung Tunggal (\%)

\begin{tabular}{cllll}
\hline Takaran & \multicolumn{3}{c}{ Jarak Tanam $(\mathrm{cm} \mathrm{x} \mathrm{cm)}$} & \multirow{2}{*}{ Rerata } \\
\cline { 2 - 4 } Pupuk (t/ha) & $5 \times 5$ & $5 \times 10$ & $10 \times 10$ & \\
\hline 10 & $60.21 \mathrm{~b}$ & $25.37 \mathrm{f}$ & $31.83 \mathrm{ef}$ & 39.14 \\
15 & $69.59 \mathrm{a}$ & $26.13 \mathrm{f}$ & $25.70 \mathrm{f}$ & 40.48 \\
20 & $53.09 \mathrm{c}$ & $45.92 \mathrm{~d}$ & $17.62 \mathrm{~g}$ & 38.87 \\
\hline Rerata & 60.96 & 32.48 & 25.05 & $(+)$ \\
\hline
\end{tabular}

Keterangan : Angka pada baris dan kolom diikuti huruf sama menunjukkan tidak berbeda pada taraf nyata $(\alpha) 5 \%$ menurut uji DMRT. $(+)=$ Tidak terjadi interaksi antar faktor.

Tabel 14. Indeks Panen (\%)

\begin{tabular}{clccc}
\hline Takaran & \multicolumn{3}{c}{ Jarak Tanam $(\mathrm{cm} \mathrm{x} \mathrm{cm)}$} & \multirow{2}{*}{ Rerata } \\
\cline { 2 - 4 } Pupuk (t/ha) & $5 \times 5$ & $5 \times 10$ & $10 \times 10$ & \\
\hline 10 & $89.97 \mathrm{~b}$ & $92.42 \mathrm{a}$ & $84.53 \mathrm{e}$ & $88.97 \mathrm{~b}$ \\
15 & $90.12 \mathrm{~b}$ & $91.41 \mathrm{a}$ & $90.23 \mathrm{~b}$ & $90.59 \mathrm{a}$ \\
20 & $91.00 \mathrm{ab}$ & $88.12 \mathrm{c}$ & $86.30 \mathrm{~d}$ & $88.47 \mathrm{~b}$ \\
\hline Rerata & $90.36 \mathrm{ab}$ & $90.65 \mathrm{a}$ & $87.02 \mathrm{~b}$ & $(+)$ \\
\hline
\end{tabular}

Keterangan : Angka pada baris dan kolom diikuti huruf sama menunjukkan tidak berbed pada taraf nyata $(\alpha) 5 \%$ menurut uji DMRT. $(+)=$ Tidak terjadi interaksi antar faktor.

Interaksi antar perlakuan terjadi terhadap indeks panen. Permberian takaran pupuk kandang sapi $15 \mathrm{t} /$ ha dengan jarak tanam $5 \mathrm{~cm} \times 10 \mathrm{~cm}$ menghasilkan indeks panen tertinggi. Pemberian takaran pupuk kandang sapi 10 dan 20 t/ha, dengan peningkatan jarak tanam cenderung menurunkan indeks panen, sedangkan pemberian takaran pupuk kandang sapi 15 t/ha indeks panen cenderung meningkat bila jarak tanam semakin meningkat (Tabel 14).

\subsection{Pembahasan}

Pengaruh interaksi antar perlakuan terhadap kondisi lingkungan pada pengamatan 25, 50 dan 75 HST tidak terjadi, dan menggambarkan keadaan lingkungan yang homogen. Namun pada pengamatan 75 HST, pengaruh utama pemberian takaran pupuk kandang sapi 15 t/ha menunjukkan rerata suhu tanah $\left(29,78{ }^{\circ} \mathrm{C}\right)$ (Tabel 2.) dan kadar lengas tanah $(16,49 \%)$ (Tabel 3.) lebih tinggi, sedangkan berat volume tanah lebih rendah $\left(1,90 \mathrm{~g} / \mathrm{cm}^{3}\right)$ dibanding takaran lainnya.

Interaksi antar perlakuan juga tidak terjadi pada pengamatan jumlah daun dan tinggi tanaman setiap waktu pengamatan menggambarkan keadaan tanaman yang homogen namun pemberian takaran pupuk $15 \mathrm{t} / \mathrm{ha}$ dengan jarak tanam 5 $\mathrm{cm} \times 5 \mathrm{~cm}$ menghasilkan tanaman dengan berat kering tajuk terberat.

Interaksi antar perlakuan berpengaruh nyata pada hasil tanaman. Jarak tanam semakin kecil meningkatkan jumlah tanaman per satuan luas, meningkatkan kompetisi, meningkatkan pula pembentukan umbi bawang putih siung tunggal pada setiap pemberian takaran pupuk kandang sapi.

Berat kering per umbi siung tunggal menunjukan bahwa pada takaran pupuk kandang $15 \mathrm{t} / \mathrm{ha}$ dengan jarak tanam $10 \mathrm{~cm}$ x $10 \mathrm{~cm}$ memberikan hasil yang tinggi karena peningkatan jarak tanam meningkatkan berat kering umbi, namun menurunkan pembentukan umbi siung tunggal.

Pemberian pupuk kandang sapi dengan takaran 15 t/ha pada jarak tanam 5 $\mathrm{cm} \times 5 \mathrm{~cm}$ menghasilkan pembentukan jumlah populasi bawang putih umbi siung tunggal paling tinggi dengan persentase $86,42 \%$, dari jumlah yang terbentuk pada jarak tanam $5 \mathrm{~cm} \times 10 \mathrm{~cm}$ mengakibatkan peningkatan hasil umbi siung tunggal tertinggi $(2,28 \mathrm{t} / \mathrm{ha})$, dan persentase berat kering umbi suing tunggalnya juga meningkat $69,59 \%$ dari berat umbi totalnya, namun pada jarak tanam $5 \mathrm{~cm}$ x 10 $\mathrm{cm}$ menghasilkan berat kering umbi total paling tinggi (4,00 t/ha), disebabkan peningkatan perolehan hasil bersama berat kering umbi majemuknya.

Dari hasil penelitian ini menunjukkan pula menurunnya jarak tanam lebih mempengaruhi terbentuknya umbi siung tunggal. Menurunnya jarang tanam dari $10 \mathrm{~cm}$ x $10 \mathrm{~cm}$ menjadi $5 \mathrm{~cm}$ x $10 \mathrm{~cm}$ demikian pula dari $5 \mathrm{~cm}$ x $10 \mathrm{~cm}$ menjadi $5 \mathrm{~cm} \times 5 \mathrm{~cm}$ meningkatkan persentase berat kering umbi siung tunggal per petak $115 \%$ untuk setiap penurunan taraf jarak tanam.

Pada penelitian ini tingkat kerapatan tanaman dengan menggunakan jarak tanam $5 \mathrm{~cm}$ x $5 \mathrm{~cm}$ (J1) yaitu sebanyak 3610000 tanaman/ha dengan berat tertinggi $2.28 \mathrm{t}$ pada takaran pupuk kandang sapi $15 \mathrm{t} / \mathrm{ha}$, diikuti dengan kerapatan $5 \mathrm{~cm} \times 10 \mathrm{~cm}(\mathrm{~J} 2)$ dengan 3120000 tanaman/ha dengan berat $1.4 \mathrm{t}$.

\section{Simpulan}

Menurunnya jarak tanam lebih mempengaruhi terbentuknya umbi bawang putih siung tunggal, persentase berat kering umbi siung tunggal per petak meningkat $115 \%$ untuk setiap taraf penurunan jarak tanam dari $10 \mathrm{~cm} \times 10 \mathrm{~cm}$ menjadi $5 \mathrm{~cm} \times 10 \mathrm{~cm}$ demikian pula dari $5 \mathrm{~cm} \times 10 \mathrm{~cm}$ menjadi $5 \mathrm{~cm} \times 5 \mathrm{~cm}$. Pemberian pupuk kandang $15 \mathrm{t} /$ ha dengan jarak tanam $5 \mathrm{~cm} \times 5 \mathrm{~cm}$ memberikan persentase jumlah pembentukan umbi bawang putih siung tunggal dengan presentase $86,42 \%$. Pemberian takaran pupuk kandang sapi 15 t/ha dengan jarak tanam $5 \mathrm{~cm}$ x $5 \mathrm{~cm}$ mampu meningkatkan hasil berat umbi bawang putih siung tunggal paling tinggi $(2,28 \mathrm{t} / \mathrm{ha})$ atau $69,59 \%$ dari berat kering umbi totalnya.

\section{Pustaka}

BPS RI (Badan Pusat Statisitik Republik Indonesia), 2013 Data Produksi Tanaman Holtikultura. Jakarta.

Direktorat Gizi Departemen Kesehatan R.I, 1997. Daftar Komposisi Bahan Makanan. Bhratara Karya Aksara : Jakarta.

Fauziah dan Hening S. 2000. Sayur dan Bumbu Dapur Berkhasiat Obat. Penebar Swadaya : Jakarta.

Gomez, K A dan Gomez A A. 1995. Prosedur Statistik untuk Penelitian Pertanian. Edisi ke 2. Jakarta: UI Press.

Rismunandar. 2003. Membudidayakan Lima Jenis Bawang. Sinar Baru Algensindo : Bandung. 